\title{
THE EFFECTIVENESS OF 70\% METHANOLIC EXTRACT OF AVOCADO LEAF (Persea americana Mill) IN DECREASING BLOOD SUGAR LEVELS IN MALE RATS (Rattus norvegicus) WISTAR STRAIN INDUCED ALLOXAN
}

\author{
THE EFFECTIVENESS OF 70\% METHANOLIC EXTRACT OF AVOCADO LEAF \\ (Persea americana Mill) IN DECREASING BLOOD SUGAR LEVELS IN MALE RATS \\ (Rattus norvegicus) WISTAR STRAIN INDUCED ALLOXAN
}

\author{
Anindita Putri Handayani, Retno Sintowati, Riandini Aisyah \\ Fakultas Kedokteran Universitas Muhammadiyah Surakarta
}

Korespondensi: dr. Retno Sintowati, Msc, Email:retno_sintowati@ums.ac.id

\begin{abstract}
ABSTRAK
Tanaman alpukat (Persea americana Mill) merupakan tanaman tradisional yang memiliki kandungan flavonoid dan tannin yang dapat menurunkan kadar gula darah. Tujuan penelitian ini adalah untuk mengetahui efektivitas ekstrak metanol 70\% daun alpukat (Persea americana Mill) terhadap penurunan kadar gula darah. Metode penelitian menggunakan eksperimental laboratorik dengan rancangan penelitian pretest - posttest with control group design. Hewan uji yang digunakan 25 ekor tikus jantan galur Wistar, umur 2-3 bulan, dan berat badan 150-200 gram yang dibagi dalam 5 kelompok. Kelompok I: kontrol negatif (aquades), kelompok II: kontrol positif (glibenklamid), kelompok III, IV, V : ekstrak metanol 70\% daun alpukat dengan dosis berturut-turut adalah sebagbai berikut: $100 \mathrm{mg} / 200 \mathrm{grBB}, 150 \mathrm{mg} / 200 \mathrm{grBB}, 200 \mathrm{mg} / 200 \mathrm{grBB}$. Gula darah diukur dengan alat spektrofotometer. Berdasarkan hasil uji ANOVA, data penurunan kadar gula darah hari ke-7 pemberian ekstrak nilai probabilitas signifikan $p=0,000$ dengan demikian $p<0$, 05 maka terdapat perbedaan penurunan kadar gula darah yang bermakna. Berdasarkan uji LSD dari semua kelompok didapatkan nilai $p<0,05$ yang berarti terdapat perbedaan penurunan kadar gula darah yang signifikan antara 2 kelompok. Kesimpulan: Ekstrak metanol $70 \%$ daun alpukat (Persea americana Mill) dosis $200 \mathrm{mg} / 200 ; 100 \mathrm{mg} / 200$ and $150 \mathrm{mg} / 200 \mathrm{gram} / \mathrm{berat}$ badan dapat menurunkan kadar gula darah pada mencit jantan galur wistar
\end{abstract}

Kata Kunci : Ekstrak metanol 70\%, Alpukat (Persea americana Mill), gula darah, diabetes mellitus.

\section{ABSTRACT}

Avocado (Persea americana Mill) is a traditional plant that contains flavonoid and tannin. These substances have an effect in decreasing blood sugar levels. The aim of this study is to determine the effect of $70 \%$ methanolic extract of avocado leaf (Persea americana Mill) in decreasing blood sugar levels. The study was an experimental laboratory pretest-posttest methods with control group design. The animals were 25 male Wistar rats 2-3 months old, 150-200 grams weight, and divided into 5 groups. Group I was negative control (aquadest)and group II was positive control(glibenclamide). Ggroup III, IV, V were trated by $70 \%$ methanolic extract of avocado leaf with doses of $100 \mathrm{mg} / 200 ; 150 \mathrm{mg} / 200 \mathrm{gbw}$ and $200 \mathrm{mg} / 200 \mathrm{gbw}$ respectively. There are significant difference between group I (negative control) and treatment control (group III, IV, V) with $p .<0.05$. Conclusion: The $70 \%$ methanolic extract of avocado leaf dose $200 \mathrm{mg} / 200 ; 100 \mathrm{mg} / 200$ and $150 \mathrm{mg} / 200 \mathrm{gbw}$ can reduce blood sugar level in male Wistar rats .

Keyword: 70\% methanolic extract, Avocado (Persea americana Mill), blood sugar, diabetes mellitus

\section{PENDAHULUAN}

Diabetes mellitus merupakan suatu gangguan metabolik menahun akibat pankreas yang tidak dapat memproduksi cukup insulin atau tubuh tidak dapat menggunakan insulin secara efektif. Insulin adalah hormon yang berfungsi mengatur keseimbangan kadar gula darah dalam tubuh. Akibatnya terjadi peningkatan konsentrasi 
glukosa didalam darah (hiperglikemia) (Kementrian Kesehatan RI, 2014).

Secara epidemiologi, prevalensi penderita Diabetes Mellitus (DM) di Indonesia mencapai 21,3 juta orang (Kementrian Kesehatan RI, 2009). Menurut Riset Kesehatan Dasar (Riskesdas, 2007) menyebutkan bahwa proporsi penyebab kematian karena DM pada kelompok usia 45-54 tahun di daerah perkotaan menduduki peringkat ke-2 dengan prevalensi $14,7 \%$, sedangkan daerah pedesaan penyebab kematian karena DM menduduki peringkat ke-6 dengan prevalensi 5,8\%.

Berdasarkan pemeriksaan gula darah, jumlah penderita DM di Indonesia dengan usia $>15$ tahun di perkotaan mencapai 5,7\% (Riskesdas, 2007). Prevalensi angka kejadian DM mencapai lebih dari 180 juta jiwa di seluruh dunia, angka ini kemungkinan akan bertambah menjadi lebih dari dua kali lipat pada tahun 2030 (Chakraborty et al., 2010).

Prevalensi penderita DM pada populasi penduduk Asia meningkat pesat dalam beberapa dekade terakhir. Tahun 2007, lebih dari 110 juta penduduk Asia baik pada usia muda atau dewasa menderita DM. Hal ini juga dipengaruhi oleh beberapa hal antara lain tingkat kelebihan berat badan dan obesitas yang meningkat, pembangunan ekonomi, gizi, dan gaya hidup yang menetap (Chan et al., 2009).

Tanaman alpukat banyak digunakan sebagai obat tradisional diantaranya untuk mengobati penyakit menorrhagia, hipertensi, sakit perut, bronkitis, diare, dan diabetes (Yasir et al., 2010) sedangkan daun alpukat (Persea americana Mill) telah banyak digunakan untuk mengobati DM di negara-negara di Amerika dan Afrika (Lima et al., 2012).

Daun alpukat memiliki kandungan kimia antara lain isorhamnetin, luteolin, rutin, quersetin, apigenin. Pada ekstrak air dan metanol daun alpukat mengandung sterol, tannin, saponin, flavonoid, alkaloid, fenol, antrakuinon, triterpen (Asaolu et al., 2010). Ekstraksi daun alpukat mempunyai efek hipoglikemik pada tikus normal. Aktivitas antidiabetes dapat dicapai pada 6 jam setelah dosis tunggal diberikan dengan jumlah penurunan kadar glukosa darah mencapai $60,02 \pm 6,83 \%$ (Antia et al., 2005). Penelitian lain oleh Arini (2013) mengenai pengaruh fraksi kloroform ekstrak etanol daun alpukat (Persea americana Mill) pada tikus putih jantan dengan metode uji toleransi glukosa efektif dapat menurunkan kadar gula darah pada dosis $1,5 \mathrm{~g} / \mathrm{kg}$ BB. Penelitian Harianto (2013) mengenai pengaruh fraksi n-butanol ekstrak etanol daun alpukat (Persea americana Mill) pada tikus putih jantan dapat menurunkan kadar gula darah efektif pada dosis 1,0 g/kg BB. Berdasarkan penelitian yang telah dilakukan sebelumnya, maka penelitian dengan varian dosis yang berbeda pada ekstrak daun alpukat (Persea americana Mill) dilakukan dengan harapan dapat memperoleh hasil dosis terbaik yang dapat menurunkan kadar gula darah.

\section{METODE}

Desain penelitian ini adalah eksperimental laboratorium dengan metode penelitian pretestpostest with control groupdesign. Penelitian ini dilaksanakan di Laboratorium Biomedik III Sub Laboratorium Farmakologi dan Laboratorium Biomedik II Sub Laboratorium Patologi Klinik Fakultas Kedokteran Universitas Muhammadiyah Surakarta. Penelitian ini dilaksanakan pada bulan November-Desember 2015.Subyek penelitian ini menggunakan ekstrak daun alpukat (Persea americana Mill).Objek yang digunakan pada penelitian ini adalah tikus putih jantan (Rattus norvegicus) galur Wistar yang dipilih secara purposive sampling dengan teknik pengelompokkan simple random sampling. Berdasarkan rumus Federer didapatkan 5 ekor tikus dalam setiap kelompok (5 kelompok) sehingga total sampel yang digunakan adalah 25 ekor tikus putih jantan (Rattus norvegicus) galur Wistar. Pada penelitian ini 5 kelompok tersebut masing-masing diberikan perlakuan sebagai kelompok kontrol negatif dengan aquadest, kelompok kontrol positif dengan glibenklamid, kelompok perlakuan ekstrak metanol 70\% daun alpukat dosis I (100 mg/ 200 grBB), kelompok perlakuan ekstrak metanol 70\% daun alpukat dosis II $(150 \mathrm{mg} / 200$ grBB), dan kelompok perlakuan ekstrak metanol $70 \%$ daun alpukat dosis III $(200 \mathrm{mg} / 200 \mathrm{grBB})$. Identifikassi variabel terdiri dari variabel bebas yaitu Ekstrak daun alpukat (Persea americana Mill) dengan skala rasio, variabel terikat yaitu kadar gula darah dengan skala rasio serta variabel luar yang terdiri dari variabel terkendali (Jenis kelamin, umur tikus, berat badan tikus, pakan, galur) dan variabel tidak terkendali (Keadaan awal pankreas tikus). Alat yang digunakan antara lain 
kandang tikus, timbangan elektronik, timbangan obat, pipa kapiler, spuit injeksi, sample cup, pisau, blender, alat vakum, mikrokapiler, pisau bedah, spektrofotometer.Bahan yang digunakan antara lain tikus putih jantan (Rattus norvegicus) galur Wistar usia 2-3 bulan dengan berat badan 150200 gram, sediaan uji atau ekstrak daun alpukat (Persea americana Mill), aloksan, aquadest, glibenklamid, alkohol $70 \%$, metanol 70\%, kapas steril.

\section{Cara Kerja:}

Langkah I : Pembuatan ekstrak metanol 70\% daun alpukat dengan cara maserasi. Pertama, daun alpukat dicuci hingga bersih dan dirajang kecilkecil kemudian diangin-anginkan hingga kering. Bahan yang kering dihaluskan menggunakan blender dengan tambahan sedikit metanol 70\%hingga didapatkan serbuk daun alpukat. Lakukan perendaman daun alpukat selama $4 \times 24$ jamdengan setiap 24 jam dilakukan penyaringan dan direndam kembali dengan menggunakan metanol yang baru kemudian hasil maserasi 1 sampai 4 disatukan. Selanjutnya dilakukan evaporasi pada suhu $30-40{ }^{\circ} \mathrm{C}$ dengan alat vakum sampaidiperoleh ekstrak kental metanol. Hasil ekstrak ini yang digunakan sebagai bahan uji.

Langkah II : Tikus yang digunakan pada penelitian diberi perlakuan dengan cara diletakkan dalam kandang dan ditempatkan pada ruangan yang cukup pencahayaan dengan suhu yang optimal. Tikus dibagi menjadi 5 kelompok dan setiap kelompoknya terdiri dari 5 ekor tikus. Tikus ditandai ekornya dan ditimbang berat badannya. Pada setiap kelompok diberikan masing-masing perlakuan yaitu kelompok I sebagai kelompok kontrol negatif yang diberikan aquadest, kelompok kontrol positif yang diberikan glibenklamid, kelompok perlakuan I dengan dosis ekstrak daun alpukat $100 \mathrm{mg} / 200$ grBB, kelompok perlakuan

\section{Hasil Pengukuran Berat Badan Tikus}

Tabel 1. Rata-Rata Berat Badan Tikus

\begin{tabular}{lll}
\hline No & \multicolumn{1}{c}{ Kelompok } & Rerata Berat Badan (gram) \pm SD \\
\hline 1. & Kontrol Negatif & $152.40 \pm 8.735$ \\
2. & Kontrol Positif & $150.80 \pm 8.497$ \\
3. & Perlakuan 1 & $153.60 \pm 7.369$ \\
4. & Perlakuan 2 & $151.80 \pm 9.203$ \\
5. & Perlakuan 3 & $153.20 \pm 11.777$ \\
\hline
\end{tabular}

Sumber : Data Primer, 2015
II dengan dosis ekstrak daun alpukat $150 \mathrm{mg} /$ 200 grBB, dan kelompok perlakuan III dengan dosis ekstrak daun alpukat $200 \mathrm{gr} / \mathrm{mgBB}$. Pada penelitian ini dilakukan pemeriksaan gula darah sebanyak 3 kali. Pemeriksaan pertama dilakukan sebelum induksi aloksan sebagai gula darah awal kemuadian gula darah pretest yaitu dilakukan 4 hari setelah induksi aloksan serta gula darah posttest yaitu 7 hari setelah diberikannya perlakuan.

Langkah III : Pemeriksaan kadar gula darah dilakukan dengan mengambil darah pada ekor tikus bagian lateralis. Ekor tikus dibersihkan dan dikeringkan terlebih dahulu dengan posisi ekor mengarah ke bawah atau lebih rendah dari badan tikus. Tikus dimasukkan dalam tabung yang berlubang sehingga ekornya dapat dikeluarkan. Kemudian ekor tikus disayat dengan menggunakan pisau dan darah yang keluar ditampung dengan pipa kapiler kemudian darah dimasukkan dalam tabung. Setelah pengambilan darah selesai, ekor tikus diberikan povidon iodin pada bagian luka. Penghitungan kadar gula darah dengan menggunakan alat spektrofotometer yang dilakukan di Laboratorium Patologi Klinik Universitas Muhammadiyah Surakarta.

Langkah IV : Masing-masing kelompok dihitung kadar gula darah. Data yang diperoleh dianalisis dengan uji statistik Shapiro-Wilk, Test of homogeneity of variance, uji t berpasangan, One Way ANOVA, dan LSD(Least Significant Differrence).

\section{HASIL DAN PEMBAHASAN}

\section{Randemen}

Rendemen ekstrak ini digunakan untuk membandingkan antara ekstrak dengan simplisia (daun alpukat). Didapatkan hasil 1 gram daun alpukat kering mengandung 0,0958 gram ekstrak kental 


\section{Hasil Uji Efek Ekstrak terhadap Penurunan Kadar Gula Darah}

Hasil Pengukuran Kadar Gula Darah

Tabel 2. Rerata Kadar Gula Darah pada Tikus Putih Jantan (Rattus norvegicus) Galur Wistar

\begin{tabular}{ccccc}
\hline Kelompok & N & $\begin{array}{c}\text { GD I } \\
\text { (Awal) } \\
(\mathbf{m g} / \mathbf{d L}) \pm \text { SD }\end{array}$ & $\begin{array}{c}\text { GD II } \\
(\text { Pretest }) \\
(\mathbf{m g} / \mathbf{d L}) \pm \text { SD }\end{array}$ & $\begin{array}{c}\text { GD III (Posttest) } \\
(\mathbf{m g} / \mathbf{d L}) \pm \text { SD }\end{array}$ \\
\hline $\begin{array}{c}\text { Kontrol (-) } \\
\text { Mean } \pm \text { SD }\end{array}$ & 5 & $120,40 \pm 12,522$ & $155,60 \pm 21,254$ & $166,60 \pm 11,502$ \\
$\begin{array}{l}\text { Kontrol (+) } \\
\text { Mean } \pm \text { SD }\end{array}$ & 5 & $127,00 \pm 8,367$ & $165,80 \pm 17,138$ & $97,80 \pm 3,493$ \\
$\begin{array}{l}\text { Perlakuan I } \\
\text { Mean } \pm \text { SD }\end{array}$ & 5 & $89,00 \pm 9,695$ & $147,00 \pm 9,670$ & $138,20 \pm 3,962$ \\
$\begin{array}{c}\text { Perlakuan II } \\
\text { Mean } \pm \text { SD }\end{array}$ & 5 & $87,60 \pm 9,503$ & $136,60 \pm 8,112$ & $126,60 \pm 2,702$ \\
$\begin{array}{c}\text { Perlakuan III } \\
\text { Mean } \pm \text { SD }\end{array}$ & 5 & $87,60 \pm 6,542$ & $148,40 \pm 13,221$ & $114,60 \pm 4,037$ \\
\hline
\end{tabular}

Sumber : Data Primer, 2015

2. Rata-Rata Penurunan Kadar Gula Darah

Tabel 3. Rerata Penurunan Kadar Gula Darah

\begin{tabular}{lcccc}
\hline Kelompok & N & $\begin{array}{c}\text { Gula Darah Pretest } \\
(\mathbf{m g} / \mathbf{d L}) \pm \text { SD }\end{array}$ & $\begin{array}{c}\text { Gula Darah } \\
\text { Posttest (mg/dL) } \\
\pm \mathbf{S D}\end{array}$ & $\begin{array}{c}\text { Penurunan Gula } \\
\text { Darah(\%) (mg/dL) } \\
\pm \text { SD }\end{array}$ \\
\hline Kontrol (-) & 5 & $155,60 \pm 21,254$ & $166,60 \pm 11,502$ & $-7,94 \pm 8,21$ \\
Kontrol (+) & 5 & $165,80 \pm 17,138$ & $97,80 \pm 3,493$ & $40,56 \pm 5,69$ \\
Dosis I & 5 & $147,00 \pm 9,670$ & $138,20 \pm 3,962$ & $5,71 \pm 5,61$ \\
Dosis II & 5 & $136,60 \pm 8,112$ & $126,60 \pm 2,702$ & $7,12 \pm 4,31$ \\
Dosis III & 5 & $148,40 \pm 13,221$ & $114,60 \pm 4,037$ & $22,29 \pm 7,19$ \\
\hline
\end{tabular}

Sumber : Data Primer, 2015

3. Hasil Analisis Statistik

a. Hasil Uji Distribusi Data

Uji distribusi data menggunakan Uji Saphiro-Wilk, uji tersebut digunakan untuk mengetahui distribusi data kelompok yang kurang dari 50 sampel. Hasil analisis Saphiro-Wilk pada pemeriksaan gula darah awal yaitu ketika tikus belum diinduksi aloksan didapatkan $\mathrm{p}=$ 0,064 , pemeriksaan gula darah pretest yaitu darah yang diambil 4 hari setelah tikus diinduksi aloksan didapatkan $\mathrm{p}$ $=0,191$, dan pemeriksaan gula darah posttest yaitu darah yang diambil setelah pemberian ekstrak selama 7 hari didapatkan $p=0,403$. Dari data yang diperoleh tersebut nilai $\mathrm{p}>0,05$ maka dapat disimpulkan bahwa data tersebut berdistribusi normal.

b. Hasil Uji Test of Homogenecity of Variance

Uji homogenitas varian dilakukan dengan menggunakan uji statistik Levene Test of Varians. Hasil dari uji ini pada pemeriksaan awal nilai $\mathrm{p}=0,234$, pemeriksaan pretest nilai $\mathrm{p}=0,157$, dan pemeriksaan posttest nilai $p=0,246$. Dari hasil uji tersebut menunjukkan data adalah homogen karena nilai $\mathrm{p}>0,05$.

Pemilihan uji statistik untuk menentukan sebuah hipotesis harus dilihat dari hasil uji distribusi data dan hasil Uji Test of Homogenecity of Varians. Setelah data diolah menggunakan SPSS, didapatkan data 
berdistribusi normal dan varians data sama (homogen) sehingga untuk uji hipotesisnya menggunakan one way ANOVA.

c. Hasil Uji t Berpasangan

Uji $\mathrm{t}$ berpasangan ini digunakan untuk mengetahui kenaikan bermakna kadar gula darah pada pemeriksaan gula darah awal dan pretest serta untuk mengetahui penurunan bermakna pada pemeriksaan gula darah pretest dan posttest. Hasil dari uji ini didapatkan nilai $p$ $=0,000$ pada pemeriksaan gula darah awal dan pretest serta didapatkan nilai $\mathrm{p}=0,001$ pada pemeriksaan gula darah pretest dan posttest. Data tersebut menunjukkan bahwa $\mathrm{p}<0,005$ yang berarti terdapat perbedaan bermakna pada peningkatan kadar gula darah awal-pretest dan terdapat perbedaan bermakna pada penurunan kadar gula darah pretest-posttest.

d. Hasil Uji one way ANOVA pada Hari Ke-7 (Gula Darah Posttest)

Pada analisis data menggunakan uji one way ANOVA didapatkan hasil nilai $\mathrm{p}=0,000$. Nilai probabilitas merupakan parameter untuk mengambil keputusan. Apabila nilai probabilitas $>0,05$ maka H1 ditolak dan H0 diterima, sebaliknya jika nilai probabilitas $<0,05$ maka $\mathrm{H} 1$ diterima dan H0 ditolak. Dari hasil uji one way ANOVA menunjukkan hasil nilai probabilitas $<0,05$ maka pada penelitian ini hipotesis $\mathrm{H} 1$ diterima dan $\mathrm{H} 0$ ditolak.

e. Hasil Uji LSD(Least Significant Difference) pada Hari Ke-7 (Gula Darah Posttest)

Setelah dilakukan uji one way ANOVA kemudian dilakukan analisis Post Hoc untuk mengetahui perbedaan signifikan antar kelompok. Alat untuk melakukan analisis Post Hoc untuk one way ANOVA adalah dengan uji Least Significant Difference $(L S D)$. Untuk pengambilan keputusan berdasarkan nilai probabilitas, jika nilai $\mathrm{p}<0,05$ maka terdapat perbedaan signifikan, sedangkan jika nilai $\mathrm{p}>0,05$ maka tidak berbeda signifikan(tabel 4 ).

Tabel 4. Uji Post Hoc Least Significant Difference (LSD)

\begin{tabular}{lcc}
\hline Kelompok & Nilai “p” & Keterangan \\
\hline KN - KP & 0,000 & Berbeda signifikan \\
KN - P1 & 0,000 & Berbeda signifikan \\
KN - P2 & 0,000 & Berbeda signifikan \\
KN - P3 & 0,000 & Berbeda signifikan \\
KP - P1 & 0,000 & Berbeda signifikan \\
KP - P2 & 0,000 & Berbeda signifikan \\
KP - P3 & 0,000 & Berbeda signifikan \\
P1 - P2 & 0,003 & Berbeda signifikan \\
P1 - P3 & 0,000 & Berbeda signifikan \\
P2 - P3 & 0,000 & Berbeda signifikan \\
\hline
\end{tabular}

Sumber : Data Primer, 2015

4. Potensi Efek Penurunan Kadar Gula Darah Kelompok Perlakuan Dibandingkan dengan Kontrol Positif (glibenklamid)

Tabel 5. Persentase Potensi Penurunan Kadar Gula Darah pada Hari Ke-7 (Gula Darah Posttest)

\begin{tabular}{lcc}
\hline Kelompok & N & Rerata Penurunan Kadar Gula Darah(\%) \\
Dosis I & 5 & $14,07 \%$ \\
Dosis II & 5 & $17,55 \%$ \\
Dosis III & 5 & $54,95 \%$
\end{tabular}

Sumber : Data Primer, 2015 
Penelitian dilakukan di laboratorium Farmakologi Universitas Muhammadiyah Surakarta yang bertujuan untuk mengetahui efektivitas ekstrak daun alpukat (Persea americana Mill) terhadap penurunan kadar gula darah pada tikus putih jantan (Rattus norvegicus) galur Wistar yang diinduksi aloksan. Dari penelitian ini dilakukan pengambilan darah sebanyak tiga kali yaitu pengambilan darah awal ketika tikus belum diinduksi aloksan, pengambilan darah pretest yaitu 4 hari setelah diinduksi aloksan, dan pengambilan darah posttest yaitu 7 hari setelah tikus diberikan ekstrak. Sebelum pengambilan darah baik awalan, pretest maupun posttest tikus dipuasakan terlebih dahulu selama 8 jam dengan tetap diberikan minum. Pengamatan pada penelitian ini dilakukan sampai 7 hari setelah pemberian ekstrak daun alpukat pada masing-masing dosis yaitu dosis I (100 mg/ 200 grBB), dosis II (150 mg/ 200 grBB), dan dosis III (200 mg/ 200 grBB).

Kadar gula darah adalah kadar gula pada darah tikus putih jantan (Rattus norvegicus) galur Wistar yang diukur dalam $\mathrm{mg} / \mathrm{dL}$ dengan menggunakan alat spektrofotometer. Data yang diperoleh dari penelitian kemudian dilakukan uji statistik dengan menggunakan program SPSS guna mengetahui nilai probabilitas efek ekstrakmetanol $70 \%$ daun alpukat (Persea americana Mill) terhadappenurunan kadar gula darah pada tikus putih jantan (Rattus norvegicus) galur Wistar yang diinduksi aloksan.

Pada analisis data menggunakan uji one way ANOVA didapatkan hasil nilai $\mathrm{p}=0,000(\mathrm{p}<$ $0,05)$ sehingga dapat disimpulkan bahwa terdapat perbedaan yang signifikan pada penurunan kadar gula darah antar kelompok hewan uji. Dari hasil uji one way ANOVA dapat ditentukan bahwa hipotesis H1 peneliti diterima. Ekstrak metanol 70\% daun alpukat (Persea americana Mill) mampu menurunkan kadar gula darah pada hewan uji. Hal ini karena pada daun alpukat (Persea americana Mill) terdapat beberapa senyawa yang berfungsi sebagai antidiabetes. Beberapa senyawa tersebut adalah flavonoid dan tannin. Flavonoid melalui sifatnya sebagai zat antioksidan bekerja dengan memperbaiki sel $\beta$ pankreas (Banjarnahor dan Artanti, 2014).Quersetin yang merupakan subkelas dari flavonoid diduga sebagai agen hipoglikemik penghambatan enzim $\alpha$ - amilase dan memiliki potensi sebagai inhibitor transpor glukosa oleh intestinal glucose transporter GLUT2 dan GLUT5 yang bertanggung jawab terhadap absorbsi glukosa pada usus halus (Wulandari, 2010). Tanninbekerja dengan mengendapkan atau mempresipitasikan protein selaput lendir di permukaan usus halus dan membentuk suatu lapisan yang melindungi usus sehingga dapat menghambat absorbsi glukosa sehingga jumlah peningkatan glukosa darah tidak terlalu tinggi (Anggraeni, 2006).

Hasil uji statistik antara kelompok kontrol negatif dengan kelompok perlakuan (KP) I, II dan III didapatkan adanya perbedaan yang signifikan $(\mathrm{p}<0,05)$. Hal tersebut menunjukkan bahwa pemberian ekstrak metanol $70 \%$ daun alpukat (Persea americana Mill) pada dosis I (100 mg/ 200 grBB), dosis II (150 mg/ 200 grBB), dan dosis III $(200 \mathrm{mg} / 200 \mathrm{grBB})$ mempunyai efek menurunan kadar gula darah. Kelompok kontrol negatif pada penelitian ini tidak mendapatkan pengobatan dan hanya diberi aquadest yang menyebabkan kerusakan sel $\beta$ pankreas oleh aloksan tetap berlangsung sehingga kadar gula darah pada tikus tetap tinggi.

HasilanalisisPostHocdenganmenggunakan uji Least Significant Difference $(L S D)$ antara kelompok kontrol positif dengan kelompok perlakuan (KP) I, II, dan III didapatkan perbedaan yang signifikan $(\mathrm{p}<0,05)$. Hal ini menunjukkan bahwa kelompok kontrol positif mempunyai efek menurunan kadar gula darah yang lebih baik dibandingkan dengan kelompok perlakuan (KP) I, II, dan III yang diberikan ekstrak metanol $70 \%$ daun alpukat (Persea americana Mill) dengan dosis I (100 mg/ 200 grBB), dosis II (150 mg/ 200 grBB), dan dosis III (200 mg/ 200 grBB). Pada kelompok kontrol positif dengan kelompok perlakuan (KP) III terjadi perbedaan yang signifikan yang menunjukkan bahwa KP III tidak bisa mendekati efektivitas kelompok kontrol positif dalam menurunkan kadar gula darah. Hal ini dapat terjadi karena obat glibenklamid ini merupakan agen hipoglikemik yang bekerja dengan merangsang sekresi insulin dari sel $\beta$ pankreas sehingga pada kontrol positif terjadi penurunan kadar gula darah yang lebih baik daripada kelompok perlakuan (KP) III serta terbatasnya waktu pengamatan yang hanya 7 hari sehingga tidak dapat diketahui kerja maksimal dari ekstrak daun alpukat (Persea americana Mill). Dapat pula terjadi karena tidak tersarinya kandungan zat pada daun alpukat 
oleh larutan metanol 70\% sehingga ekstrak yang digunakan tidak dapat bekerja secara maksimal.

Antara kelompok perlakuan didapatkan hasil KP I (dosis I $100 \mathrm{mg} / 200$ grBB) terhadap KP II (dosis II $150 \mathrm{mg} / 200$ grBB) berbeda signifikan $(\mathrm{p}<0,05)$. Hal ini menunjukkan KP II mempunyai efek menurunan kadar gula darah lebih baik dari KP I. Pada KP I terhadap KP III didapatkan perbedaan yang signifikan $(p<0,05)$. Hal ini menunjukkan bahwa KP III (dosis $200 \mathrm{mg}$ / 200 grBB) mempunyai efek menurunan kadar gula darah lebih baik dibandingkan KP I (dosis $100 \mathrm{mg} / 200 \mathrm{grBB}$ ).

Hasil yang diperoleh dari analisis statistik menunjukkan bahwa pemberian ekstrak metanol $70 \%$ daun alpukat (Persea americana Mill) pada tikus putih jantan (Rattus norvegicus) galur Wistar yang diinduksi aloksan dapat menurunkan kadar gula darah meskipun belum bisa menyamai kekuatan glibenklamid sebagai agen hipoglikemik pada pengelolaan DM. Hal ini menunjukkan bahwa kandungan flavonoid dan tannin dalam daun alpukat (Persea americana Mill) mempunyai efek menurunkan kadar gula darah pada hewan uji. Flavonoid yang terkandung dalam daun alpukat (Persea americana Mill) diduga sebagai agen hipoglikemik (Banjarnahor dan Artanti, 2014). Pada tannin diduga memiliki kemampuan untuk menghambat absorbsi glukosa sehingga peningkatan glukosa darah tidak terlalu tinggi (Anggraeni, 2006).

Kadar gula darah yang tinggi pada hewan uji ini terjadi karena adanya induksi dari aloksan yang bertindak sebagai induktor hiperglikemik yang menyebabkan kerusakan pada sel $\beta$ pankreas pada tikus. Kerusakan sel $\beta$ pankreas tersebut akan menurunkan produksi insulin sehingga dapat menurunkan pengambilan glukosa ( glukosa uptake menurun). Hal inilah yang menyebabkan kadar gula darah pada hewan uji meningkat. Dari proses tersebut maka dibutuhkan perbaikan pada sel $\beta$ pankreas untuk menghasilkan insulin yang digunakan untuk mengikat gula darah sehingga kadar gula darah dapat menurun.

Keterbatasan pada penelitian ini adalah tidak dikendalikannya faktor-faktor yang mempengaruhi penurunan kadar gula darah seperti kemungkinan adanya gangguan pada organ dalam tikus, kelainan genetik, dan kecemasan. Selain itu, kurangnya variasi konsentrasi dosis ekstrak untuk menghasilkan dosis efektif dalam menurunkan kadar gula darah serta tidak dilakukannya fraksinasi dan isolasi senyawa yang terkandung dalam daun alpukat (Persea americana Mill) sehingga tidak dapat diketahui secara pasti kandungan senyawa yang memiliki kemampuan sebagai antidiabetik untuk menurunkan kadar gula darah.

\section{SIMPULAN}

Pemberian ekstrak metanol $70 \%$ daun alpukat (Persea americana Mill) dosis I (100 $\mathrm{mg} / 200 \mathrm{grBB})$, dosis II (150 mg/ $200 \mathrm{grBB})$ dan dosis III (200 mg/200 grBB) dapat menurunkan kadar gula darah pada tikus putih jantan (Rattus Norvegicus) galur Wistar yang diinduksi aloksan.

Pemberian ekstrak metanol $70 \%$ daun alpukat (Persea americana Mill) pada dosis III (200 mg/ 200 grBB) memberikan efek yang lebih baik dalam menurunkan kadar gula darah dari dosis I (100 mg/ 200grBB) dan dosis II (150 $\mathrm{mg} / 200$ grBB) pada tikus putih jantan (Rattus norvegicus) galur Wistar yang diinduksi aloksan belum dapat menyamai efek penurunan kadar gula darah pada kelompok kontrol positif yang diberikan glibenklamid.

\section{DAFTAR PUSTAKA}

Anggraeni, A.D.2006. Pengaruh Pemberian Infusa Biji Alpukat (Persea americana Mill) Terhadap Kadar Glukosa Darah Tikus Wistar Yang Diberi Beban Glukosa. Universitas Diponegoro Semarang. Skripsi

Antia, B.S., Okokon, J.E., Okon, P.A.2005. Hipoglicemic Activity of Aqueous Leaf Extract of Persea americana Mill. Indian J Pharmacol. 37:325-6.

Arini, Ni G.K. S.2013. Pengaruh Fraksi Kloroform Ekstrak Etanol Daun Alpukat (Persea americana Mill) Terhadap Penurunan Kadar Glukosa Darah pada Tikus Putih Jantan dengan Metode Uji Toleransi Glukosa [CDROM]. Widya Mandala Catolic University Surabaya. Thesis.

Asaolu,M.F., Asaolu, S.S., \& Adanlawo, I.G.2010. Evaluation of Phytochemicals and ntioxidants of Four Botanicals with Antihypertensive Properties. Int J Pharma Bioscience, 1 (2):1-7 
Badan Penelitian dan Pengembangan Kesehatan. Riset Kesehatan Dasar (Riskesdas). 2007. Jakarta: Badan Penelitian dan Pengembangan Kesehatan; 2007.

Banjarnahor, S. D.S., Artanti, N.2014. Antioxidant Properties of Flavonoids. Med J Indones:23(4).

Chakraborty, A. K., S. Rhambade., U.K. Patil., A. Rambhade.(2010). Diabetes Melitus - Its Complications, Factors Influencing Complications and Prevention- An Overview. $J$ Chem Pharmaceutical Res,;2(6): 7-25.

Chan, J. C. N.; Malik, V.; Jia, W.; Kadowaki, T.; Yajnik, C. S.; Yoon, K.H; Hu, F. B.2009. Diabetes in Asia Epidemiology, Risk Factors, and Pathophysiology. JAMA; 301 (20):2129-40

Harianto, S.2013. Pengaruh Fraksi n Butanol Ekstrak Etanol Daun Alpukat (Persea americana Mill) Terhadap Penurunan Kadar Glukosa Darah pada Tikus Putih Jantan dengan Metode Uji Toleransi Glukosa. Widya Mandala Catolic University Surabaya. Thesis.
Kementrian kesehatan RI.2009. Profil Kesehatan Indonesia. Jakarata.

Kementrian Kesehatan RI.2014. Pusat Data dan Informasi. Jakarta Selatan

Lima, C. R., Vasconcelos, C.F.B., Costa-Silva, J.H., Maranhão, C.A., Costa, J., Batista, T.M., Carneiro, E.M., Soares, L.A.L., Ferreira, F., Wanderley, A.G.2012. Anti-diabetic activity of extract from Persea americana Mill. Leaf Via the Activation of Protein Kinase B (PKB/Akt) in Streptozotocin Induced Diabetic Rats. $J$ Ethnopharmacol; 141(1): 517-25.

Wulandari, C.E.2010.PengaruhPemberian Ekstrak Bawang Merah (Allium ascalonicum) Terhadap Penurunan Kadar Glukosa Darah Pada Tikus Wistar dengan Hiperglikemia. Karya Tulis Ilmiah: Fakultas kedokteran, Universitas Diponegoro Semarang.

Yasir, M.,Das, S., Kharya, M.D.2010. The Phytochemical and Pharmacological Profile of Persea americana Mill. Pharmacognosy Rev;4:7 77-84.. 